\title{
The Purification and Properties of the $C_{1}$ Component of Trichoderma koningii Cellulase
}

\author{
By T. M. WOOD and SHEILA I. McCRAE \\ Rowett Research Institute, Bucksburn, Aberdeen AB2 9SB, U.K.
}

(Received 25 February 1972)

\begin{abstract}
1. The $\mathrm{C}_{1}$ component that was isolated from a Trichoderma koningii cellulase preparation (Wood, 1968) by chromatography on DEAE-Sephadex with a salt gradient was still associated with a trace of CM-cellulase activity (determined by reducing-sugar and viscometric methods). 2. Further chromatography on DEAE-Sephadex, with a pH gradient instead of a salt gradient, provided a $\mathrm{C}_{1}$ component that could still produce reducing sugars from a solution of CM-cellulose (to a very limited extent), but which could no longer decrease the viscosity (i.e. under the assay conditions employed). 3. No evidence for the non-identity of $C_{1}$ component and the trace of CM-cellulase activity could be found when electrofocusing was done in a stabilized $\mathrm{pH}$ gradient covering three pH units (pH3-6) or, alternatively, only $0.5 \mathrm{pH}$ unit (pH3.72-4.25). 4. The two protein peaks that were separated by electrofocusing in carrier ampholytes covering only $0.5 \mathrm{pH}$ unit (isoelectric pH values of 3.80 and 3.95) were shown to be isoenzymes of the $C_{1}$ component: they differed in the extent to which they were associated with carbohydrate $(9 \%$ and $33 \%) .5$. The purified $\mathrm{C}_{1}$ component had little ability to attack CMcellulose or highly ordered forms of cellulose, but degraded phosphoric acid-swollen cellulose readily: cellobiose was the principal product of the hydrolysis $(97 \%)$. 6. Dewaxed cotton fibre was degraded to the extent of $15 \%$ when exposed to high concentrations of $\mathrm{C}_{1}$ component over a prolonged period: cellobiose was again the principal sugar present in the supernatant $(96 \%) .7$. Cellotetraose and cellohexaose were hydrolysed almost exclusively to cellobiose. 8. Evidence indicates that the $C_{1}$ component is a $\beta-1,4-$ glucan cellobiosylhydrolase.
\end{abstract}

Certain cellulolytic fungi, when grown on media containing cotton fibres as sole carbon source, synthesize and release into solution all of the enzymes that are essential for the breakdown of native cellulose. Notable in this regard are the fungi Trichoderma viride (Mandels \& Reese, 1964; Li et al., 1965; Niwa et al., 1965; Ogawa \& Toyama, 1965, 1967, 1968; Selby \& Maitland, 1967; Okada et al., 1968), Trichoderma koningii (Iwasaki et al., 1964; Halliwell, 1965; Wood, 1968), Penicillium funiculosum (Selby, 1968) and Fusarium solani (Wood \& Phillips, 1969). Some of the fractionation studies carried out on culture filtrates prepared from these fungi (Mandels \& Reese, 1964; Selby \& Maitland, 1967; Wood, 1968; Selby, 1968; Wood, 1969) have shown them to contain three enzymes, or classes of enzymes, which are essential for the extensive hydrolysis of highly ordered forms of cellulose. Two of these types of enzymes have been arbitrarily called $C_{1}$ and Cx (Reese et al., 1950); the third is a cellobiase or $\beta$-glucosidase.

Enzymes classified as $\mathrm{C}_{\mathbf{x}}$ can hydrolyse swollen, soluble, or partially degraded celluloses, but are unable to attack highly ordered substrates, such as the cotton fibre. $C_{1}$ component has little or no effect on either soluble derivatives of cellulose (such as CM-cellulose) or highly ordered substrates (Selby \& Maitland, 1967; Wood, 1968, 1969, 1971), but acts synergistically with $C_{x}$ enzyme(s) and cellobiase to accomplish the conversion of native cellulose into water-soluble products (Mandels \& Reese, 1964; Selby \& Maitland, 1967; Wood, 1968, 1969).

$C_{x}$ enzyme(s) and cellobiase, then, are hydrolases, but what is the function of the $C_{1}$ component? According to the original concept of Reese et al. (1950), the action of $C_{1}$ component on highly ordered forms of cellulose is a prerequisite to hydrolysis by the $C_{x}$ enzymes. Since then it has been tentatively suggested that this prehydrolysis step might be one involving attack on hydrogen bonds (Siu, 1963), anomalous linkages, 'weak' linkages or atypical residues in the cellulose chains (Mandels \& Reese, 1964). Yet another theory envisages $C_{1}$ component to be an enzyme capable, on its own, of solubilizing 'crystalline' hydrocellulose (Li et al., 1965; Flora, 1965; Ogawa \& Toyama, 1967; Okada et al., 1968), 
although acting synergistically with the $C_{x}$ components to bring about an increase in the rate of hydrolysis.

The present report describes the further purification of the $C_{1}$ component already isolated (Wood, 1968) and presents evidence which indicates that $C_{1}$ component is a $\beta-1,4$-glucan cellobiosylhydrolase.

\section{Experimental}

\section{Materials}

T. koningii, culture collection no. I.M.I. 73022 , was obtained from the Commonwealth Mycological Institute, Kew, Surrey, U.K. Sodium CM-cellulose (Cellofas B) with a degree of substitution of approx. 0.5 was kindly given by Imperial Chemical Industries Ltd., Nobel Division, Stevenston, Ayrshire, U.K. Texas cotton fibre was obtained from the Shirley Institute, Didsbury, Manchester, U.K. Sephadex G-25, Sephadex G-75, DEAE-Sephadex (A-50) and the glass chromatographic columns were purchased from Pharmacia (G.B.) Ltd., London W.5, U.K. Ampholine electrofocusing equipment and the carrier ampholytes were supplied by L.K.B. Instruments Ltd., Croydon, Surrey, U.K., and Kieselgel G was from Shandon Scientific Co., London N.W.10, U.K. Glucose oxidase (type II) was obtained from Sigma (London) Chemical Co., London S.W.6, U.K., and the peroxidase from Boehringer Corp. (London) Ltd., London W.5, U.K. $\beta$-1,2-Glucan (Rhizopus japonicus) and $\beta$-1,6-glucan (Penicillium luteum) were gifts from Dr. J. S. D. Bacon, Macaulay Institute for Soil Research, Aberdeen, U.K., and laminarin (from Laminarai hyperborea), amylopectin (from potato), amylose (from potato), glycogen (from oyster), nigeran (from Aspergillus niger) and dextran (source unspecified) were purchased from Koch-Light Laboratories, Colnbrook, Bucks., U.K. Avicel (microcrystalline cellulose) was obtained from Honeywill and Stein Ltd., London W.1, U.K.

\section{Methods}

Preparation of T. koningii cellulase. Cultures and cell-free filtrates were prepared from $T$. koningii I.M.I. 73022 by the method previously described (Wood, 1968).

A concentrated culture filtrate (50-fold) was prepared by precipitation of the culture filtrate with $\left(\mathrm{NH}_{4}\right)_{2} \mathrm{SO}_{4}$ between the limits of 20 and $80 \%$ saturation, and then centrifuging and redissolving the precipitate in $0.1 \mathrm{M}$-acetic acid- $\mathrm{NaOH}$ buffer, pH 5.0. Enzyme assays indicated that all of the cellulase (cotton solubilization), CM-cellulase and cellobiase activity of the original culture filtrate was recovered.

Preparation of phosphoric acid-swollen cellulose (Walseth cellulose; Walseth, 1952). Avicel was swollen by the method detailed by Wood (1971).

Isoelectric focusing. The separations were carried out according to the method first described by Vesterberg \& Svensson (1966). The L.K.B. column used had a capacity of $110 \mathrm{ml}$. The density gradient (sucrose) was made manually (see the L.K.B. instruction manual) by mixing a 'light solution' (containing water and ampholyte) and a 'dense solution' (containing water, ampholytes and sucrose) in different proportions. The sample to be electrofocused was added to the column near the middle by replacing the light component of the density gradient by the sample solution. The dense electrode solution contained phosphoric acid $(0.2 \mathrm{ml})$, water $(14.0 \mathrm{ml})$ and sucrose $(12.0 \mathrm{~g})$ and the light electrode solution contained sodium hydroxide $(0.1 \mathrm{~g})$ and water $(10.0 \mathrm{ml})$. The electrodes were placed so that the anode was at the bottom of the column.

After focusing at $5^{\circ} \mathrm{C}$ the column was emptied at a rate of $120 \mathrm{ml} / \mathrm{h}$ and fractions (approx. $2 \mathrm{ml}$ ) were collected. The $\mathrm{pH}$ of each fraction was measured at $5^{\circ} \mathrm{C}$ with a Radiometer $\mathrm{pH}$-meter fitted with a combination electrode and a temperature compensator.

Paper chromatography. Paper chromatography was carried out on Whatman no. 1 filter paper in solvent A, ethyl acetate-pyridine-water (10:4:3, by vol.). Chromatograms were sprayed, after air-drying, with silver nitrate (Trevelyan et al., 1950).

Thin-layer chromatography. Plates $(20 \mathrm{~cm} \times 20 \mathrm{~cm})$ were coated with a $0.25 \mathrm{~mm}$-thick layer of Kieselgel $\mathrm{G}$, dried at $100^{\circ} \mathrm{C}$ and stored in a desiccator before use. Chromatograms were developed (two ascents) in solvent $B$, ethyl acetate-propan-2-ol-water (18:13:9, by vol.). The plate was dried at room temperature and sprayed with silver nitrate (see above) or a $2 \%(w / v)$ solution of sodium periodate in $5 \%(\mathrm{v} / \mathrm{v})$ acetic acid, followed by a $0.5 \%$ solution of potassium permanganate in $4 \%(\mathrm{w} / \mathrm{v}) \mathrm{NaOH}$.

Determination of protein. Protein was measured by the method of Lowry et al. (1951), with crystalline bovine serum albumin as standard.

Determination of reducing sugars. Reducing sugars were determined either by the Somogyi-Nelson method (Nelson, 1952) or by the method of Park \& Johnson (1949) modified to include $\mathrm{FeNH}_{4}\left(\mathrm{SO}_{4}\right)_{2}$ solution made up in $0.075 \mathrm{M}-\mathrm{H}_{2} \mathrm{SO}_{4}$ instead of $0.025 \mathrm{M}-\mathrm{H}_{2} \mathrm{SO}_{4}$. The reducing value in each case was expressed as glucose equivalent.

Determination of glucose. Glucose was measured by glucose oxidase (see under cellobiase assay; Wood, 1969) and/or one of the reducing-sugar methods mentioned above.

Determination of total carbohydrate. Total carbo- 
hydrate was measured by the phenol- $\mathrm{H}_{2} \mathrm{SO}_{4}$ method of Dubois et al. (1956).

$C_{x}$ activity. $\mathrm{C}_{\mathrm{x}}$ activity was measured in two ways: (a) the decrease in the viscosity of a CM-cellulose solution (Wood, 1971); (b) the appearance of reducing sugars in a solution of CM-cellulose. In the viscometric method it was found that, under the conditions of the assay, the plot of rate of increase of the reciprocal of the viscosity against the enzyme concentration was linear up to at least a value of $0.027 \mathrm{~min}^{-1}$ (Thomas, 1956). A value of $0.020 \mathrm{~min}^{-1}$ was found for $1.0 \mathrm{ml}$ of the $20-80 \%$-satd.- $\left(\mathrm{NH}_{4}\right)_{2} \mathrm{SO}_{4}$ fraction diluted 2500 -fold, and this was chosen as the unit of activity.

In the reducing-sugar method a mixture of $2.5 \mathrm{ml}$ of the $1 \%$ solution of CM-cellulose, $1.5 \mathrm{ml}$ of $0.2 \mathrm{M}$ acetic acid- $\mathrm{NaOH}$ buffer, pH5.4, and $1.0 \mathrm{ml}$ of diluted enzyme and water was incubated at $37^{\circ} \mathrm{C}$ for $1 \mathrm{~h}$. A sample $(1.0 \mathrm{ml})$ of this reaction mixture was taken and the reducing sugars present were measured by the method of Park \& Johnson (1949) modified as stated above. The unit of activity is defined as the amount of enzyme needed to liberate reducing sugar equivalent to $5 \mu \mathrm{g}$ of glucose.

A sample $(1.0 \mathrm{ml})$ of the $20-80 \%$-satd.- $\left(\mathrm{NH}_{4}\right)_{2} \mathrm{SO}_{4}$ fraction, diluted 50-fold, contained 1820 units of CMcellulase activity when assayed by the reducing-sugar method [hereafter called CM-cellulase activity (reducing sugar)] and 50 units of CM-cellulase activity when measured by the viscometric method [hereafter called CM-cellulase activity (viscometric)].

Cellobiase activity. Cellobiase was determined by the method described by Wood (1969).

Activity towards dewaxed cotton. The degree of solubilization (referred to as 'cellulase activity' in the Results section) is defined as the extent to which $2 \mathrm{mg}$ of dewaxed cotton fibre is solubilized in 7 days when incubated with enzyme at $37^{\circ} \mathrm{C}$ under the conditions of the standard assay (Wood, 1969).

Activity towards phosphoric acid-swollen cellulose, Avicel and Whatman cellulose powder (no. 1). Each substrate was suspended in water so that $1.0 \mathrm{ml}$ contained approx. $1 \mathrm{mg}$ of cellulose (determined by the dichromate- $\mathrm{H}_{2} \mathrm{SO}_{4}$ method described by Wood, 1969). $\mathrm{NaN}_{3}$ (final concn. $0.02 \%$ ) was added as preservative.

Assays for enzymic activity towards these substrates consisted of $2 \mathrm{ml}$ of substrate suspension, $2.5 \mathrm{ml}$ of $0.2 \mathrm{M}$-acetic acid- $\mathrm{NaOH}$ buffer, $\mathrm{pH} 4.8$, and enzyme and water to give a total volume of $5 \mathrm{ml}$. After incubation at $37^{\circ} \mathrm{C}$ for the times stated, the residual cellulose was assayed by the dichromate$\mathrm{H}_{2} \mathrm{SO}_{4}$ method described previously (Wood, 1969).

Preparation of cello-oligosaccharides. Cello-oligosaccharides were prepared by the acetolysis of dewaxed cotton fibres and then were separated by gradient elution ( $0-35 \%$ ethanol) from a charcoalCelite $(1: 1, w / w)$ column.

\section{Results}

Separation of the $C_{1}$ component from $C_{x}$ and cellobiase activities

It has been demonstrated that the removal of a lowmolecular-weight $C_{x}$ component from culture filtrates from Trichoderma species (Selby \& Maitland, 1967; Wood, 1968) does not affect the kinetics of solubilization of cotton fibre. The low-molecular-weight component isolated in one case (Wood, 1968) had little capacity for solubilizing cotton fibre and was unable to form 'short-fibres' (Halliwell, 1965). All of the 'short-fibre'-forming activity as well as all of the solubilization activity shown by the unfractionated culture filtrate was associated with the high-molecular-weight component. This behaviour contrasts with that shown by the low-molecular-weight component that was incompletely separated from the highermolecular-weight material by Halliwell \& Riaz(1970).

In the present investigation relatively large quantities of $C_{1}$ component were prepared from T. koningii cellulase as follows: the low-molecularweight component was first removed from a sample $(10 \mathrm{ml})$ of the concentrated cell-free filtrate $[20-80 \%$ satd.- $\left(\mathrm{NH}_{4}\right)_{2} \mathrm{SO}_{4}$ fraction] on a column $(2.5 \mathrm{~cm} \times$ $93.0 \mathrm{~cm}$ ) of Sephadex G-75 equilibrated with $0.01 \mathrm{M}-$ acetic acid-ammonium acetate buffer, pH5.0. The high-molecular-weight material was combined and freeze-dried. Three such fractionations were done and the high-molecular-weight components were combined and applied to a column $(5.0 \mathrm{~cm} \times 30.2 \mathrm{~cm})$ of DEAE-Sephadex (acetate form). The $C_{x}$ and cellobiase components were eluted under the starting conditions (0.1 M-acetic acid- $\mathrm{NaOH}$ buffer, $\mathrm{pH} 5.0)$ as previously described (Wood, 1968), and the $C_{1}$ component was finally desorbed by the application of an ionic-strength gradient $(0-0.5 \mathrm{M}-\mathrm{NaCl})$. The separated components were precipitated with $\left(\mathrm{NH}_{4}\right)_{2} \mathrm{SO}_{4}(80 \%$ saturation), centrifuged, and redissolved in $0.1 \mathrm{M}$-acetic acid- $\mathrm{NaOH}$ buffer, $\mathrm{pH} 5.0$ $(30 \mathrm{ml})$.

The $\mathrm{C}_{1}$ component was still associated with a trace of CM-cellulase activity, but this only amounted to $0.03 \%$ of the CM-cellulase activity (viscometric) and $0.6 \%$ of the CM-cellulase activity (reducing-sugar) of the CM-cellulase activity applied to the column.

Portions of the $\mathrm{C}_{1}$ - and the $\mathrm{C}_{\mathrm{x}}$-cellobiase components were diluted so that the volumes were equivalent in terms of the unfractionated $20-80 \%$ satd.-( $\left.\mathrm{NH}_{4}\right)_{2} \mathrm{SO}_{4}$ material, diluted 50 -fold. Under these conditions, $1.0 \mathrm{ml}$ of the diluted $\mathrm{C}_{1}$ component and $1.0 \mathrm{ml}$ of the diluted $\mathrm{C}_{\mathrm{x}}$-cellobiase component solubilized cotton fibres to the extent of 4 and $6 \%$ respectively (see the Experimental section for the standard assay), whereas an assay mixture containing $1.0 \mathrm{ml}$ of each gave $69 \%$ solubilization. Since, under the same conditions, $1.0 \mathrm{ml}$ of the original culture filtrate also gave $69 \%$ solubilization of cotton, it was 
clear that there had been no loss in cellulase activity as a result of various manipulations.

It was found that $1.0 \mathrm{ml}$ of the $\mathrm{C}_{1}$ component, diluted as described above, contained $180 \mu \mathrm{g}$ of protein, and $1 \mathrm{ml}$ of the diluted $\mathrm{C}_{\mathrm{x}}$-cellobiase component contained 35 units of CM-cellulase activity (viscometric), 1510 units of CM-cellulase activity (reducing sugar) and 32 units of cellobiase activity. In each of the subsequent fractionation procedures reported in the present paper, the recovery of $C_{1}$ activity was determined by doing reconstitution experiments for the solubilization of cotton in which $180 \mu \mathrm{g}$ of $\mathrm{C}_{1}$ component was mixed with $1.0 \mathrm{ml}$ of the diluted $\mathrm{C}_{x}$ cellobiase fraction just described.

\section{Further purification of the $C_{1}$ component on DEAE-} Sephadex

Further chromatography of the partially purified $\mathrm{C}_{1}$ component on DEAE-Sephadex, with a $\mathrm{pH}$ gradient (pH4.8-3.6) with formic acid- $\mathrm{NaOH}$ buffer of ionic strength 0.1 , resulted in the removal of another $\mathrm{C}_{\mathrm{x}}$ component (Fig. 1). The major protein component $\left(\mathrm{C}_{1}\right)$, which was eluted at $\mathrm{pH} 3.95$, still possessed a very limited ability to produce reducing sugars from a solution of CM-cellulose, but now showed no capacity for decreasing the viscosity. Similar results were obtained by the gradient $(\mathrm{pH})$ elution of $\mathrm{C}_{1}$ component from three other DEAESephadex columns in which the ionic strength of the formate buffers were $0.01,0.05$ or 0.15 : under these conditions the $\mathrm{C}_{1}$ component was eluted at $\mathrm{pH} 3.54$, 3.72 and 4.2 , respectively.

Recovery of protein (Fig. 1) was $93 \%$.

Reconstitution experiments for cellulase (solubilization) activity were again done, in which the highly purified $C_{1}$ component and the separated $C_{x}$-cellobiase fraction were mixed in their original proportions (see above): $95 \%$ of the cotton-solubilization activity of the original cellulase complex was re-

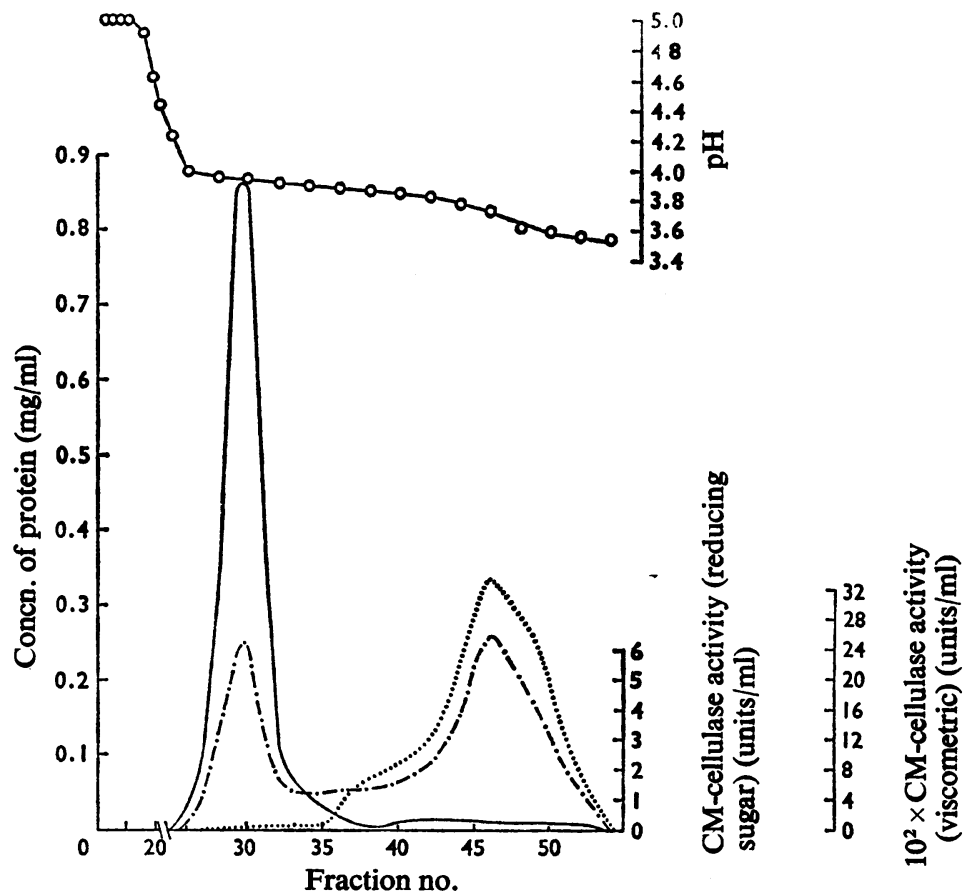

Fig. 1. Further purification of the $C_{1}$ component on a column $(21.6 \mathrm{~cm} \times 1.5 \mathrm{~cm})$ of $D E A E-S e p h a d e x$ equilibrated with $0.1 \mathrm{M}$-formic acid-NaOH buffer, $\mathrm{pH} 4.8$

A sample $(2.5 \mathrm{ml})$ of the $\mathrm{C}_{1}$ component that had been eluted from the DEAE-Sephadex (acetate form) column with a $\mathrm{NaCl}$ gradient (see the text) was desalted on a column of Sephadex G-25 $(43.2 \mathrm{~cm} \times 2.6 \mathrm{~cm}$; equilibrated with $0.01 \mathrm{M}$-acetic acid-ammonium acetate buffer, $\mathrm{pH} 5.0$ ), freeze-dried, redissolved in $0.1 \mathrm{M}$-formic acid$\mathrm{NaOH}$ buffer, $\mathrm{pH} 4.9(6 \mathrm{ml})$, and applied to the DEAE-Sephadex column. The column was eluted at a rate of $15 \mathrm{ml} / \mathrm{h}$ with a pH gradient formed by adding $150 \mathrm{ml}$ of $0.1 \mathrm{M}$-formic acid- $\mathrm{NaOH}$ buffer, pH3.5, to $150 \mathrm{ml}$ of $0.1 \mathrm{M}$-formic acid- $\mathrm{NaOH}$ buffer, $\mathrm{pH} 4.8$. Fractions $(4.2 \mathrm{ml})$ were collected. Assays were done as described in the text and the results are shown as CM-cellulase activity (reducing sugar) (.-.-.) and CM-cellulase activity (viscometric) $(\cdots)$. The $\mathrm{pH}$ of the fractions is shown as 0 and the concentration of protein as - 


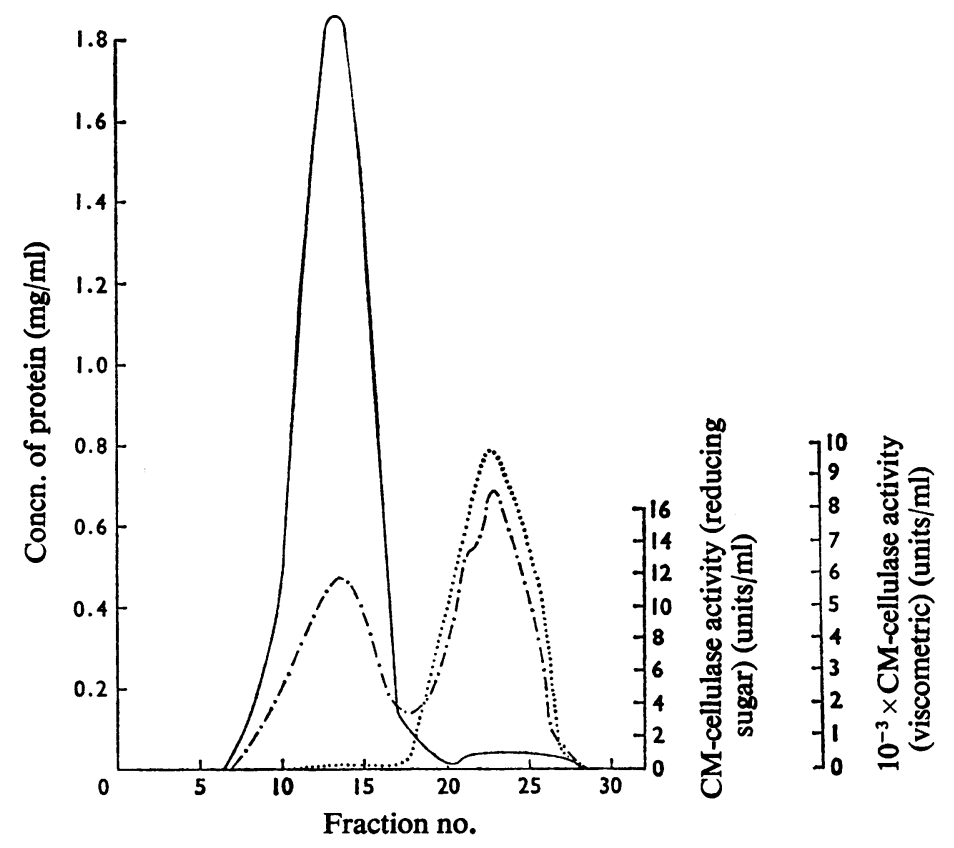

Fig. 2. Recycling chromatography of $C_{1}$ component on Sephadex $G-75$

A sample (5.0 ml) of the $C_{1}$ component that had been eluted from the DEAE-Sephadex (acetate form) column with a $\mathrm{NaCl}$ gradient (see the text) was desalted on a column of Sephadex G-25 $(43.2 \mathrm{~cm} \times 2.6 \mathrm{~cm}$; equilibrated with $0.01 \mathrm{M}$-acetic acid-ammonium acetate buffer, $\mathrm{pH}$ 5.0), freeze-dried, redissolved in $0.1 \mathrm{M}$-acetic acid- $\mathrm{NaOH}$ buffer, pH 5.0, $(5.0 \mathrm{ml})$ and applied to a column $(2.5 \mathrm{~cm} \times 69 \mathrm{~cm})$ of Sephadex G-75. The column was fitted with two Pharmacia (see the Experimental section) end units. The column was eluted (upward flow) at $4 \mathrm{ml} / \mathrm{h}$ and the eluate was monitored at $280 \mathrm{~nm}$ (LKB Uvicord II). The component that was detected as a peak of extinction was cycled four times through the same column before being eluted. Fractions $(3.0 \mathrm{ml})$ were collected. CMcellulase activity (reducing sugar) is shown as ....., CM-cellulase activity (viscometric) as $\cdots$... and concentration of protein as -

covered. $\mathrm{C}_{1}$ component acting in isolation still gave $4 \%$ solubilization under the conditions of the standard assay.

In the assay containing the reconstituted mixture of enzymes, the CM-cellulase activity (reducing sugar) associated with the $C_{1}$ component amounted to only 1.5 units; this compares with the total of 1510 units of CM-cellulase activity (reducing sugar) in the assay.

\section{Recycling on Sephadex G-75}

Recycling chromatography on a long column of Sephadex G-75 (Fig. 2) was found to be as effective as DEAE-Sephadex (Fig. 1) in removing the small CM-cellulase component from $C_{1}$ component. The large protein peak was surprisingly sharp considering that it had been cycled four times through the column.
Isoelectric focusing of the $C_{1}$ component in a $\mathrm{pH}$ gradient in the range pH3-6

The purified $C_{1}$ component (Fig. 1) prepared for electrofocusing as detailed in the legend to Fig. 3, was focused in a stabilized $\mathrm{pH}$ gradient covering the range $\mathrm{pH} 3-6$. The fractions that were collected were worked up by precipitating the enzyme with $\left(\mathrm{NH}_{4}\right)_{2} \mathrm{SO}_{4}(80 \%$ saturation), centrifuging, dialysing and freeze-drying. This procedure was adopted only after several attempts at removing the ampholytes by dialysis through Visking tubing were unsuccessful; the complete removal of ampholytes was found to be necessary, as even traces were found to interfere with the protein and CM-cellulase assays.

Fig. 3 shows a typical elution pattern after electrofocusing for $66 \mathrm{~h}$. As with ion-exchange chromatography (Fig. 1) and gel filtration (Fig. 2), no evidence for the non-identity of the $C_{1}$ component and the 


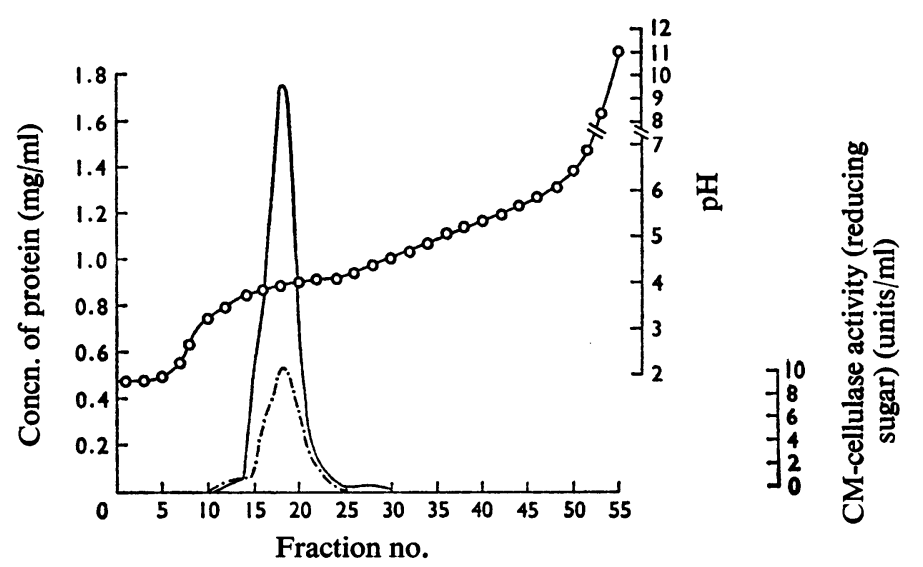

Fig. 3. Isoelectric focusing of the $C_{1}$ component with ampholyte covering range pH3-6

The $\mathrm{C}_{1}$ component from the DEAE-Sephadex column (Fig. 1) was precipitated with $\left(\mathrm{NH}_{4}\right)_{2} \mathrm{SO}_{4}(80 \%$ saturation), desalted on a column $(43.2 \mathrm{~cm} \times 2.6 \mathrm{~cm})$ of Sephadex G-25 equilibrated with $0.01 \mathrm{M}$-acetic acid-ammonium acetate buffer, $\mathrm{pH} 5.0$, and freeze-dried. The freeze-dried $\mathrm{C}_{1}$ components from two such fractionations were combined $(20 \mathrm{mg})$, dissolved in $2 \%$ ampholyte solution, $\mathrm{pH} 3-6(10 \mathrm{ml})$, and incorporated into the sucrose density gradient (see the Experimental section). The final voltage employed during the electrofocusing was $600 \mathrm{~V}$; this gave a load of approx. $1 \mathrm{~W}$. After focusing for $66 \mathrm{~h}$ the contents of the column were pumped out through the bottom. Fractions $(2.0 \mathrm{ml})$ were collected. Each fraction was precipitated with $\left(\mathrm{NH}_{4}\right)_{2} \mathrm{SO}_{4}(80 \%$ saturation), centrifuged, redissolved in $0.01 \mathrm{M}$-acetic acid-ammonium acetate buffer, pH 5.0, dialysed against $0.01 \mathrm{M}$-acetic acid-ammonium acetate buffer at $4^{\circ} \mathrm{C}$ for 6 days, freeze-dried and redissolved in $0.1 \mathrm{M}$-acetic acid$\mathrm{NaOH}$ buffer, pH4.8 $(5.0 \mathrm{ml})$. Fractions were assayed as detailed in the Experimental section. CM-cellulase activity (reducing sugar) is shown as .-.-., concn. of protein as - and the $\mathrm{pH}$ of the fractions as 0 .

trace of CM-cellulase activity (reducing sugar) could be found: both were isoelectric at pH3.95.

Protein recovery was $89 \%$.

Reconstitution experiments for cellulase (solubilization) activity done as described above indicated that $90 \%$ of the cellulase activity of the $20-80 \%$ satd.- $\left(\mathrm{NH}_{4}\right)_{2} \mathrm{SO}_{4}$ fraction was recovered.

Although only one protein peak was observed (Fig. 3), the leading edge was always characterized by a slight shoulder. For this reason an ampholyte solution covering only $0.5 \mathrm{pH}$ unit was prepared.

\section{Preparation of narrow-pH-range ampholyte solution}

A density gradient was prepared in the usual way (see the Experimental section), but the concentration of the ampholytes (pH3-5) was increased to $8 \%$. No enzyme was added at this stage. During electrofocusing the load was kept below $3 \mathrm{~W}$. After $24 \mathrm{~h}$ a white precipitate was formed at the bottom of the column at the interface of the dense electrode solution (anode) and the ampholyte solution. At the end of the run $(142 \mathrm{~h})$ the voltage was steady at $460 \mathrm{~V}$ and the current at $6 \mathrm{~mA}$. To avoid mixing the white precipitate with the ampholyte $\mathrm{pH}$ gradient, the contents of the column were removed through the top of the column by way of a capillary tube and a pump, the capillary tube being kept just below the surface of the liquid during the operation. Despite this departure from the normal emptying procedure, the $\mathrm{pH}$ gradient that was formed was subsequently found to be remarkably linear. Fractions covering the $\mathrm{pH}$ range $3.72-4.25$ were combined to give an approx. $8 \%$ ampholyte-sucrose solution.

Isoelectric focusing of the $C_{1}$ component in a $\mathrm{pH}$ gradient covering only $0.5 \mathrm{pH}$ unit

The approx. $8 \%$ ampholyte-sucrose solution covering the $\mathrm{pH}$ range $3.72-4.25$ was used to prepare the column for a normal electrofocusing run (see the Experimental section): the final ampholyte concentration in the column was approx. $1.5 \%$. The sucrose concentration in the pre-run was not taken into account when making up the new density gradient. Enzyme $\left(C_{1}\right.$ from Fig. 1) was prepared for electrofocusing as detailed in the legend to Fig. 3 and dissolved in narrow-range ampholyte solution $(10 \mathrm{ml})$ prepared as described above.

Fig. 4 shows that the minor protein component that had appeared as a shoulder to the main peak when $\mathrm{C}_{1}$ component was electrofocused in a $\mathrm{pH}$ 


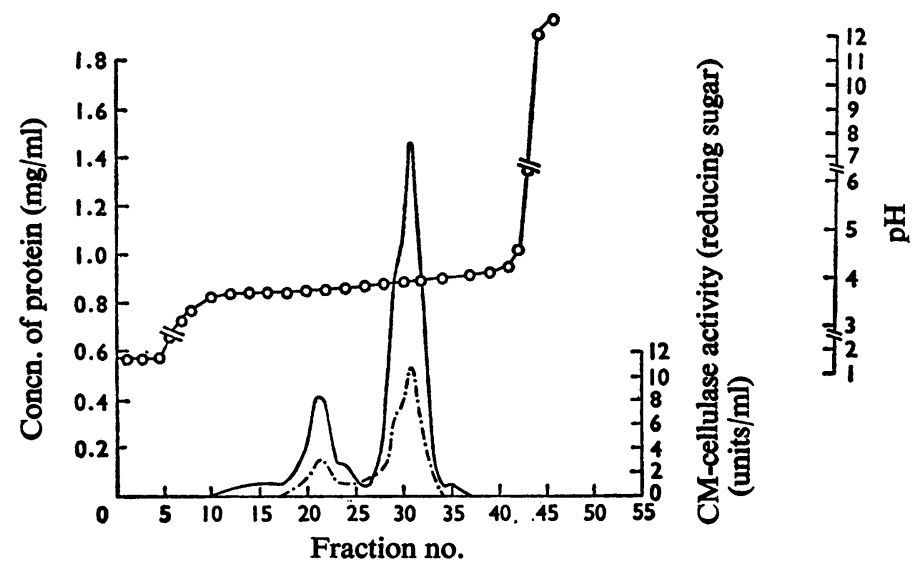

Fig. 4. Isoelectric focusing of the $C_{1}$ component in ampholyte pH3.72-4.25

The narrow-pH-range ampholyte was prepared from an ampholyte mixture covering the range pH3-5 as described in the text. The partially purified $C_{1}$ component $(20 \mathrm{mg})$, prepared for isoelectric focusing as detailed in the legend to Fig. 3, was dissolved in the prepared ampholyte solution covering the $\mathrm{pH}$ range 3.72-4.25 and was added to the column as described in the Experimental section. The voltage at the end of the run ( $90.5 \mathrm{~h})$ was $720 \mathrm{~V}$ and the current $3 \mathrm{~mA}$. The column was emptied by pumping water into the top of the column at a rate of $120 \mathrm{ml} / \mathrm{h}$. Fractions $(2.4 \mathrm{ml})$ were worked up as before (see legend to Fig. 3) and assayed for protein (-) by the method of Lowry et al. (1951), and for CM-cellulase activity (reducing sugar) (.-...). The pH of the fractions is shown as 0 .

gradient covering the range pH 3-6 (Fig. 3) was now clearly separated in ampholyte $\mathrm{pH}$ range $3.72-4.25$. The minor peak accounted for $24 \%$ of the protein recovered from the column. Another shoulder had also appeared on the main peak (fraction 29).

Both minor (isoelectric pH3.8) and major (isoelectric pH3.95) protein peaks were still associated with traces of $\mathrm{CM}$-cellulase activity (reducing sugar) and both were equally effective in solubilizing cotton fibres when acting in synergism with $\mathbf{C}_{\mathbf{x}}$ component and cellobiase (Table 1). When acting in isolation the minor protein component solubilized cotton to the extent of $2 \%$, whereas the major protein component produced $4 \%$ solubilization.

The minor and major protein components were found to be associated with 33 and $9 \%$ of carbohydrate respectively [carbohydrate was determined as glucose equivalent by the phenol- $\mathrm{H}_{2} \mathrm{SO}_{4}$ method and protein was determined by the method of Lowry et al. (1951); see the Experimental section].

\section{Activity of the $C_{1}$ component towards other glucans}

The specificity of the $C_{1}$ component (Fig. 3) was studied by incubating polysaccharide $(0.5 \mathrm{mg})$, enzyme $(50 \mu \mathrm{g}), \mathrm{NaN}_{3}(1 \mu \mathrm{g})$ and $0.01 \mathrm{M}$-acetic acid$\mathrm{NaOH}$ buffer, pH5.0 $(0.05 \mathrm{ml})$, for $18 \mathrm{~h}$ at $37^{\circ} \mathrm{C}$. A sample $(10 \mu \mathrm{l})$ was spotted on paper chromatograms: these were subsequently run in solvent $A$ (see the
Experimental section) and sprayed with $\mathrm{AgNO}_{3}-$ $\mathrm{NaOH}$ solution. No degradation products were found when the following glucans were tested as substrates: $\beta$-1,2-glucan, $\beta$-1,6-glucan (lutean), $\beta$-1,3-glucan (laminarin), mixed $\alpha-1,4-$ and $\alpha-1,3$-glucan (nigeran), mixed $\alpha-1,4-$ and $\alpha$-1,6-glucan (glycogen and amylopectin), $\alpha$-1,6-glucan (dextran) and $\alpha$-1,4-glucan (amylose). Lichenin was slightly degraded; chromatography of the products of hydrolysis showed a spot with the same mobility as cellobiose in solvent $\mathbf{A}$ and a trace of glucose.

\section{$C_{1}$ activity towards cello-oligosaccharides}

Activity towards cellobiose, cellotriose, cellotetraose, cellopentaose and cellohexaose was studied by using the same amount of enzyme, buffer etc. as used for the glucans (see above). The reaction mixtures were incubated at $37^{\circ} \mathrm{C}$ for $2 \mathrm{~h}$ and $18 \mathrm{~h}$. Both $C_{1}$ components that had been separated by isoelectric focusing (Fig. 4) were used. Chromatographic examination of the products [on paper (solvent A) or t.l.c. plates (solvent B)] showed that whereas cellobiose was not attacked, cellotriose was broken down very slowly to produce cellobiose and glucose. Cellotetraose and cellohexaose were rapidly hydrolysed and yielded mainly cellobiose; traces of cellotriose and glucose were also present, but these were 
only apparent on heavily spotted chromatograms. Cellopentaose yielded cellobiose and cellotriose with only traces of glucose.

Table 1. Cellulase activity of the $C_{1}$ components separated by isoelectric focusing when recombined with $C_{x}$ and cellobiase

The isoelectric focusing of the $C_{1}$ component is described in Fig. 4. The recovery of $C_{1}$ activity in the two protein peaks shown in Fig. 4 (i.e. fractions 18-24 and 27-33) was determined by recombining each of these pooled fractions with the $C_{x}$-cellobiase component (separated from $C_{1}$ component by chromatography on DEAE-Sephadex; see the text) and then measuring the extent to which $2 \mathrm{mg}$ of cotton fibre was solubilized in 7 days (see the Experimental section for standard cellulase assay). In these reconstitution experiments all components were recombined in the same proportions in which they were present in $1 \mathrm{ml}$ of $20-80 \%$-satd.-( $\left(\mathrm{NH}_{4}\right)_{2} \mathrm{SO}_{4}$ fraction, diluted 50-fold (see the text for details).

\begin{tabular}{|c|c|c|}
\hline $\mathrm{C}_{1}$ component & $\begin{array}{c}\text { Amount of } \\
\mathrm{C}_{1} \text { protein } \\
\text { recombined with } \\
\mathrm{C}_{\mathbf{x}} \text {-cellobiase } \\
\text { component } \\
(\mu \mathrm{g})\end{array}$ & $\begin{array}{c}\text { Solubiliza- } \\
\text { tion } \\
(\%)\end{array}$ \\
\hline Fractions 18-24 & $137^{*}$ & 59 \\
\hline Fractions $18-24$ & 43 & 9 \\
\hline Fractions $27-33$ & 137 & 60 \\
\hline ractions $18-24+$ & $43)$ & \\
\hline fractions $27-33$ & \begin{tabular}{c|c}
+ & 180 \\
137
\end{tabular} & 59 \\
\hline$C_{1}$ componen & 180 & 66 \\
\hline
\end{tabular}

(Fig. 1)

* The correct proportion of $C_{1}$ component in fractions 18-24 is $43 \mu \mathrm{g}: 137 \mu \mathrm{g}$ was added to compare the cellulase activity of that part of the $C_{1}$ component in fractions 18-24 with that part in fractions $27-33$.

\section{$C_{1}$ activity towards cellulose substrates}

Although $\mathrm{C}_{1}$ component showed little capacity for solubilizing Avicel, Whatman cellulose powder or dewaxed cotton (Table 2), cellulose that had been previously swollen in phosphoric acid was readily hydrolysed. When the supernatant from the digestion of phosphoric acid-swollen cellulose was deionized [Amberlite resins IR-45 $\left(\mathrm{OH}^{-}\right)$and IR-120 $\left(\mathrm{H}^{+}\right)$] and examined on paper chromatograms run in solvent A, only cellobiose was detected in any quantity; the small amount of glucose that was also present was shown to account for only $3 \%$ of the total carbohydrate present (Table 2).

Dewaxed cotton was attacked only slowly in an assay mixture containing the same amount of $C_{1}$ component as was present in $1 \mathrm{ml}$ of unfractionated cell-free filtrate. When the period of incubation was extended to 28 days, solubilization was increased from 4 to $7 \%$. By using double and treble the original concentration of enzyme, the respective degrees of solubilization were increased to 9 and $15 \%$ in 28 days. Paper chromatography (solvent $\mathrm{A}$ ) of the supernatant isolated from the assay showing the highest degree of solubilization (i.e. $15 \%$, with a fourfold concentration of $\mathrm{C}_{1}$ component for 28 days) again showed cellobiose to be the main product of $C_{1}$ action; as with phosphoric acid-swollen cellulose only small amounts of glucose were present. Table 3 shows in fact that the glucose represented only $4 \%$ of the total carbohydrate present in the supernatant.

Both the $C_{1}$ components that had been separated by isoelectric focusing in narrow-pH-range ampholyte solution (Fig. 4) readily hydrolysed phosphoric acid-swollen cellulose; in each case the products of the hydrolysis were cellobiose and a trace of glucose.

The products of hydrolysis of phosphoric acidswollen cellulose were cellobiose and a trace of glucose regardless of the extent of the degradation of the substrate.

\section{Discussion}

$C_{x}$ activity is normally determined by measuring either the decrease in viscosity or the increase in

\section{Table 2. Degree of solubilization of miscellaneous substrates exposed to the $C_{1}$ component for various times}

The assay is described in the Experimental section. The $C_{1}$ component used was that isolated after electrofocusing (Fig. 3): a sample containing $180 \mu \mathrm{g}$ of $\mathrm{C}_{1}$ protein was added to each assay mixture (see the text for explanation of the amount used).

\begin{tabular}{|c|c|c|c|c|}
\hline $\begin{array}{r}\text { Time } \\
\text { (h) } \\
2\end{array}$ & $\begin{array}{c}\text { Solubilization } \\
\text { of phosphoric } \\
\text { acid-swollen } \\
\text { cellulose }(\%) \\
19\end{array}$ & $\begin{array}{c}\text { Solubilization } \\
\text { of Avicel } \\
(\%) \\
\text { Nil }\end{array}$ & $\begin{array}{c}\text { Solubilization } \\
\text { of Whatman } \\
\text { cellulose }(\%) \\
\text { Nil }\end{array}$ & $\begin{array}{c}\text { Solubilization } \\
\text { of dewaxed } \\
\text { cotton }(\%) \\
\text { Nil }\end{array}$ \\
\hline $\begin{array}{r}19 \\
44 \\
168\end{array}$ & $\begin{array}{l}52 \\
72 \\
86\end{array}$ & $\begin{array}{l}2 \\
5 \\
7\end{array}$ & $\begin{array}{l}1 \\
1 \\
2\end{array}$ & $\begin{array}{l}1 \\
2 \\
4\end{array}$ \\
\hline
\end{tabular}




\section{Table 3. Digestion of dewaxed and phosphoric acid-swollen cellulose with $C_{1}$ component}

The phosphoric acid-swollen cellulose was prepared as described previously (Wood, 1971) and was digested with $\mathrm{C}_{1}$ enzyme $(180 \mu \mathrm{g}$; Fig. 3$)$ for 3 days in the assay described in the Experimental section. The dewaxed cotton was digested with the $C_{1}$ component for 28 days with a threefold concentration of enzyme $(540 \mu \mathrm{g}$; Fig. 3$)$ and the residual cellulose was measured by the dichromate- $\mathrm{H}_{2} \mathrm{SO}_{4}$ method as described previously (Wood, 1969).

$\begin{array}{ccc}\begin{array}{c}\text { Total carbohydrate } \\ \text { by phenol- } \mathrm{H}_{2} \mathrm{SO}_{4} \text { method } \\ \text { (glucose equivalent, } \mu \mathrm{g})\end{array} & \begin{array}{c}\text { Glucose by } \\ \text { glucose oxidase }\end{array} & \begin{array}{c}\text { Solubilization } \\ (\mu \mathrm{g})\end{array} \\ 1220 & 40 & (\%) \\ 320 & 12 & 87 \\ & & 15\end{array}$

reducing power of a solution of CM-cellulose. In actual fact these two methods of assay cannot always be regarded as alternatives. On the one hand the reducing-sugar method would favour the detection of a $C_{x}$ type of enzyme that would attack the CMcellulose from the chain ends, whereas on the other hand, the viscometric method would favour the detection of a $C_{x}$ type of enzyme attacking the long CM-cellulose chains at random. In this regard it is noteworthy that both endoglucanase and exoglucanase activities have been shown to exist in Trichoderma cellulase preparations ( $\mathrm{Li}$ et al., 1965; Okada et al., 1968).

In the main, individual reports in the literature about the separation of the $C_{1}$ and $C_{x}$ components present in the culture filtrates of certain cellulolytic fungi have involved only one of these methods of assaying $C_{x}$ activity (Selby \& Maitland, 1967; Eriksson, 1969). By using both methods of assay we have shown that the $C_{1}$ component of $T$. koningii, which was earlier reported to contain a trace of CMcellulase activity (reducing sugar) after displacement from DEAE-Sephadex with a salt gradient (Wood, 1968), in fact also contained CM-cellulase activity (viscometric). However, further chromatography of the purified $\mathrm{C}_{1}$ component on DEAE-Sephadex, with a $\mathrm{pH}$ gradient, has now resulted in the separation of another small peak of $C_{x}$ activity. This peak contained (under the assay conditions used) all of the CM-cellulase activity (viscometric) as well as part of the CM-cellulase activity (reducing sugar) of the $C_{1}$ component that was put on the column. No evidence for the non-identity of the $C_{1}$ component and the residual CM-cellulase activity (reducing sugar) could be found by further chromatography on DEAE-Sephadex (under a variety of conditions), by recycling chromatography on Sephadex G-75 or by isoelectric focusing in a stabilized gradient covering the $\mathrm{pH}$ range 3-6. Further, although isoelectric focusing in an ampholyte solution covering only $0.5 \mathrm{pH}$ unit resolved $\mathrm{C}_{1}$ enzyme into a major and a minor component, both of these still possessed the capacity of producing reducing sugars from CM- cellulose, albeit to a very limited extent. This latter evidence is particularly convincing and there now seems little doubt that $C_{1}$ activity and the trace of CM-cellulase activity (reducing sugar) originate in the same enzyme protein.

Both major and minor components isolated by electrofocusing were the $C_{1}$ type of enzymes. This was clearly established when it was observed that either component acted synergistically with the $\mathrm{C}_{\mathrm{x}}$-cellobiase component to the same extent in the solubilization of cotton. In fact these components appeared to be isoenzymes, for no function of one component was observed that was not equally a function of the other. The components did differ, however, in the extent of their association with carbohydrate $(9$ and $33 \%$ ), and this was, in all probability, the cause of the apparent heterogeneity observed on electrofocusing. The nature of the association of the protein and the carbohydrate is not yet known, but it is noteworthy that protein-carbohydrate complexes have already been shown to be responsible for the existence of multiple components in other 'cellulase' $\left(C_{x}\right)$ systems (Jermyn, 1955; Eriksson \& Pettersson, 1968).

The purified $C_{1}$ component of $T$. koningii showed minimal activity towards highly ordered substrates, such as dewaxed cotton fibre, Whatman cellulose powder or Avicel, when assayed over 7 days. However, in the same period, a highly amorphous substrate, phosphoric acid-swollen cellulose, was extensively degraded; the hydrolysate consisted of $97 \%$ cellobiose and 3\% glucose. Cellobiose was also the primary product $(96 \%)$ in the hydrolysate of dewaxed cotton that had been $15 \%$ degraded by exposure to a high concentration of $C_{1}$ component for 28 days. No traces of higher cello-oligosaccharides were detected in either case.

These findings, when considered together with the observation that cellobiose was produced almost exclusively when cellotetraose and cellohexaose were exposed to $C_{1}$ component, are clearly compatible with the interpretation that $C_{1}$ enzyme is a $\beta-1,4$ glucan cellobiosylhydrolase.

$C_{1}$ enzyme can therefore be regarded as a specific 
type of $C_{x}$ component that is unable to attack CM-cellulose or highly ordered substrates to any significant extent, but which is still capable of degrading more accessible forms of cellulose by removing successive units of cellobiose from the chain ends. Highly ordered ('crystalline') cellulose substrates would have relatively few chain ends accessible to the $C_{1}$ enzyme, whereas highly hydrated swollen celluloses (with relatively low degrees of polymerization) would have many. Presumably the chain ends on CM-cellulose are too highly substituted for enzyme binding to occur: $C_{1}$ action would therefore be effectively blocked once the unsubstituted cellobiose residues were removed.

The observation that cellobiose is virtually the sole product of the hydrolysis of a cellulose substrate by a $\mathrm{C}_{1}$-type enzyme has also been reported by $\mathrm{Li}$ et al. (1965). However, the 'hydrocellulase' that was isolated from a $T$. viride cellulase preparation differed from the $\mathrm{C}_{1}$ component of $T$. koningii in still retaining the capacity for producing extensive hydrolysis of 'crystalline' cellulose. In one other report (Gilligan \& Reese, 1954), the $C_{1}$-type component that was isolated (from another $T$. viride cellulase preparation) by chromatography on a calcium phosphate-gel column resembled $T$. koningii $\mathrm{C}_{1}$ component in several respects: it displayed very little CM-cellulase activity, but hydrolysed phosphoric acid-swollen cellulose to cellobiose. The ability to solubilize cotton was not tested.

Highly ordered cellulose substrates are converted rapidly into soluble sugars only when $C_{1}$ and $C_{x}$ enzymes are present in the solution simultaneously (Selby \& Maitland, 1967; Wood, 1968). We consider, therefore, that the part played by $C_{1}$ component in the degradation of these substrates will be concerned with the hydrolysis of the new chain ends that will be formed by the randomly acting endoglucanases. The function of the endoglucanases $\left(C_{x}\right)$ will be to increase the effective concentration of accessible end groups for the endwise-acting cellobiohydrolase. $C_{\mathbf{x}}$ component, and not $\mathrm{C}_{1}$ component, as originally suggested by Reese et al. (1950), can therefore be assigned the role of initiating the attack on native cellulose.

This mechanism, although supplying one possible explanation for the synergism displayed when $C_{1}$ and $C_{x}$ enzymes are present in admixture, still does not explain why the $C_{1}$ and $C_{x}$ enzymes are individually both capable of degrading swollen cellulose, but not highly ordered forms of cellulose, yet when acting in concert can solubilize highly ordered forms of cellulose with comparative ease. The precise mechanism of synergistic action between the $C_{1}$ and $C_{x}$ components at the site of attack still requires elucidation.

We thank Miss Margaret Cockburn for technical assistance and Dr. J. S. D. Bacon, Macaulay Institute for
Soil Research, for the gift of samples of $\beta-1,2-$ and $\beta$-1,6-glucan.

\section{References}

Dubois, M., Gilles, K., Hamilton, J. K., Rebers, P. A. \& Smith, F. (1956) Anal. Chem. 28, 350-356

Eriksson, K.-E. (1969) in Cellulases and Their Applications (Gould, R. F., ed.), pp. 58-59, American Chemical Society Publications, Washington, D.C.

Eriksson, K.-E. \& Pettersson, B. (1968) Arch. Biochem. Biophys. 124, 142-148

Flora, R. M. (1965) Ph.D. Thesis, Virginia Polytechnic Institute; University Microfilms (65-2041), Ann Arbor, Mich.

Gilligan, W. \& Reese, E. T. (1954) Can. J. Microbiol. 1, 90-107

Halliwell, G. (1965) Biochem. J. 95, 270-281

Halliwell, G. \& Riaz, M. (1970) Biochem. J. 116, 3542

Iwasaki, T., Hayashi, K. \& Funatsu, M. (1964)J. Biochem. (Tokyo) 63, 209-212

Jermyn, M. A. (1955) Aust. J. Biol. Sci. 8, 541-577

Li, L. H., Flora, R. M. \& King, K. W. (1965) Arch. Biochem. Biophys. 111, 439-447

Lowry, O. H., Rosebrough, N. J., Farr, A. L. \& Randall, R. J. (1951) J. Biol. Chem. 193, 265-275

Mandels, M. \& Reese, E. T. (1964) Develop. Ind. Microbiol. 5, 5-20

Nelson, N. (1944) J. Biol. Chem. 153, 376-380

Niwa, T., Kawamura, K. \& Nisizawa, K. (1965) Proc. Symp. Cellulases and Related Enzymes 5th. pp. 44-59, Cellulase Association, Osaka University, Japan

Ogawa, K. \& Toyama, N. (1965) Proc. Symp. Cellulases and Related Enzymes 5th. pp. 85-92, Cellulase Association, Osaka University, Japan

Ogawa, K. \& Toyama, N. (1967) Hakko Kogaku Zasshi 45, 671-680

Ogawa, K. \& Toyama, N. (1968) Hakko Kogaku Zassi 46, 367-374

Okada, G., Nisizawa, K. \& Suzuki, H. (1968) J. Biochem. (Tokyo) 63, 591-607

Park, J. T. \& Johnson, M. J. (1949) J. Biol. Chem. 181, 149-151

Reese, E. T., Siu, R. G. H. \& Levinson, H. S. (1950) J. Bacteriol. 59, 485-497

Selby, K. (1968) Proc. Int. Biodeterioration Symp. 1st. pp. 62-78

Selby, K. \& Maitland, C. C. (1967) Biochem. J. 104, 716-724

Siu, R. G. H. (1963) Advan. Enzymic Hydrolysis Cellulose Related Materials, Proc. Symp., 257-259

Thomas, R. (1956) Aust. J. Biol. Sci. 9, 159-183

Trevelyan, W. E., Procter, D. P. \& Harrison, J. S. (1950) Nature (London) 166, 444-445

Vesterberg, O. \& Svensson, H. (1966) Acta Chem. Scand. 20, 820-834

Walseth, C. S. (1952) Tappi 35, 228-233

Wood, T. M. (1968) Biochem. J. 109, 217-227

Wood, T. M. (1969) Biochem. J. 115, 457-464

Wood, T. M. (1971) Biochem. J. 121, 353-362

Wood, T. M. \& Phillips, D. R. (1969) Nature (London) 222, 986-987 